\title{
Quantifying predation on Baltic cod early life stages
}

\author{
Neumann, Viola; Schaber, Matthias; Eero, Margit; Böttcher, Uwe; Köster, Fritz
}

Published in:

Canadian Journal of Fisheries and Aquatic Sciences

Link to article, DOI:

10.1139/cjfas-2016-0215

Publication date:

2017

Document Version

Peer reviewed version

Link back to DTU Orbit

Citation (APA):

Neumann, V., Schaber, M., Eero, M., Böttcher, U., \& Köster, F. (2017). Quantifying predation on Baltic cod early life stages. Canadian Journal of Fisheries and Aquatic Sciences, 74(6), 833-842. https://doi.org/10.1139/cjfas2016-0215

\section{General rights}

Copyright and moral rights for the publications made accessible in the public portal are retained by the authors and/or other copyright owners and it is a condition of accessing publications that users recognise and abide by the legal requirements associated with these rights.

- Users may download and print one copy of any publication from the public portal for the purpose of private study or research.

- You may not further distribute the material or use it for any profit-making activity or commercial gain

- You may freely distribute the URL identifying the publication in the public portal

If you believe that this document breaches copyright please contact us providing details, and we will remove access to the work immediately and investigate your claim 
1 Quantifying predation on Baltic cod early life stages

2

3

4 Viola Neumann ${ }^{1 *}$ Matthias Schaber ${ }^{2}$, Margit Eero ${ }^{1}$, Uwe Böttcher ${ }^{3}$ and Friedrich W 5 Köster $^{1}$

6

1. Technical University of Denmark, National Institute of Aquatic Resources, 8 Charlottenlund Castle, Jaegersborg Allé 1, 2920 Charlottenlund, Denmark

2. Thünen-Institute of Sea Fisheries, Palmaille 9, 22767 Hamburg, Germany

3. Thünen-Institute of Baltic Sea Fisheries, Alter Hafen Süd 2, 18069 Rostock, Germany

13 e-mail:

14 M. Schaber: matthias.schaber@bund.de

15 M. Eero: mee@aqua.dtu.dk

16 U. Böttcher: uwe.boettcher@thuenen.de

$17 \quad$ F.W. Köster: fwk@aqua.dtu.dk

18

19

* Corresponding author: ph.: (+ 45) 35883300 fax: (+ 45) 35883333

20

e-mail: vneu@aqua.dtu.dk

21

22

23 


\section{Abstract}

25 Predation on cod eggs by sprat and herring is known to be one of the processes 26 influencing reproductive success of the Eastern Baltic cod, and has been reported to 27 have contributed to lack of recovery of the stock in the 1990s. This study quantifies the 28 predation on cod eggs in the Bornholm Basin, the major spawning area of cod in the 29 central Baltic Sea, in the 1990's in comparison to the second half of the 2000s. The analyses involve estimating daily consumption rates of predator populations, which are

31 then compared with corresponding daily egg production rates. As a methodological 32 advancement compared to earlier studies, spatially resolved information on predator 33 distribution and abundance is utilized in quantifying predator stock size. This resulted in 34 more realistic consumption estimates in relation to overall egg production, compared to 35 earlier studies that consistently overestimated predation pressure by clupeids. Our 36 results suggest a generally lower predation pressure on cod eggs in the mid- to late37 2000s, due to a combination of reduced predator abundance and lower daily rations by 38 individual predators.

Keywords: Baltic Sea, Atlantic cod, sprat, herring, egg production, egg consumption, 41 recruitment 


\section{Introduction}

In the Baltic Sea, cod (Gadus morhua L.) is the main predator fish (Sparholt 1994), 50 being both of high ecological and commercial importance (e.g., Rudstam et al. 1994, 51 Kornilovs et al. 2001). The eastern Baltic cod was in a depleted state in the 1990s-early 52 2000s, due to a combination of high fishing intensity and reproductive failure (Bagge et al. 1994, Köster et al. 2003, MacKenzie et al. 2000). At the same time, the Baltic sprat (Sprattus sprattus) population was record high, due to low predation pressure from cod

Quantifying predation pressure exerted by pelagic fish on early life stages has proven to be extremely difficult (Bailey and Houde 1989, Heath 1992). The studies on this topic are scarce (Houde 2008), despite the general advancements in observation technology and ecosystem understanding. Predation on early life stages is also highly variable; in the Baltic Sea depending, amongst others, on hydrographical conditions (Köster et al. 
702000 and et al. 2011). Challenges in quantifying egg predation are apparent also in the 71 Baltic Sea, as the magnitude of daily cod egg consumption has consistently been 72 estimated to be higher than production. Thus, the results have only been used as 73 relative predation indices in modelling studies (Köster et al. 2005, 2009). The largest 74 source of uncertainty was introduced by estimates of the predator population size in cod 75 spawning areas at spawning time (Köster et al. 2005). In line with this observation, 76 Paradis et al. (1996) concluded that it will be essential to study factors that influence the 77 timing of encounters between early life stages of fish and potential predators. 78 Accordingly, quantifying effective predator population size is the major methodological 79 focus of the present study.

81 The aim of the present study is to quantify cod egg predation by sprat and herring in the 82 Bornholm Basin, i.e. the main cod spawning area in the Baltic Sea (Köster et al. 2009). 83 Köster and Möllmann (2000) have estimated cod egg consumption rates in the late 1980s until the mid-1990s. Since then, several ecological changes have taken place in 85 the Baltic Sea, which can be expected to have impacted on egg predation, such as 86 expanded spawning season of cod (Neumann et al. 2014) and changed predator 87 distribution (Casini et al. 2004). Furthermore, the eastern Baltic cod stock has been 88 estimated to have increased in the second half of the 2000s (ICES 2016) which has 89 been associated with improved recruitment (Eero et al. 2012a, 2015), despite pertaining 90 adverse environmental conditions for cod in the Baltic Sea. This calls for updated 91 information on the major processes acting on cod recruitment, including predation 92 pressure. In this study we estimate cod eggs predation in 2004-2008 and compare this 
93 with updated estimates from the 1990s to elucidate potential changes in predation 94 mortality on cod eggs. In this respect, the present study is a follow-up to Neumann et al. 95 (2014) that demonstrated changes in the diet composition of sprat and herring in 2004962008 compared to the 1990s. In our investigation, we use this information to quantify 97 predation pressure on cod eggs, with major focus on methodological improvements of 98 calculation procedures compared to earlier studies, such as quantifying the effective 99 predator stock size. Our study contributes new quantitative knowledge on one of the key 100 processes governing cod recruitment in the Baltic Sea and provides both ecological and 101 methodological input to similar investigations elsewhere.

\section{Materials and Methods}

\section{Data}

106 The analyses combine i) diet composition data of sprat and herring, ii) hydrographic 107 measurements and gastric evacuation modelling to estimate the daily cod egg 108 consumption by individual predators, iii) stock assessment model output and 109 hydroacoustic surveys to derive spatially-resolved predator abundances and iv) cod egg

110 abundances and production rates from ichthyoplankton surveys conducted concurrently 111 to the stomach sampling. The data sources and calculation procedures are described 112 in detail below.

Field sampling

115 Data on diet composition of sprat and herring, cod egg abundance and vertical 116 distribution, hydrographic conditions and clupeid abundances were collected during 
117 standard hydrography/ichthyoplankton and trawl/hydroacoustic surveys in the Bornholm 118 Basin by German RV "Alkor" in 2004-2008. Corresponding data from 1990-1999 were 119 available from earlier studies (Köster and Möllmann 2000; STORE 2003). Sampling was 120 conducted in the Bornholm Basin (Fig. 1) twice a year in May/June and July/August, 121 further referred to as spring and summer, respectively.

Sprat and herring were collected for diet composition analyses deploying an "Engel Kombitrawl (KT) or an "Engel Young Fish Trawl" (YFT) (see also Neumann et al. 2014). Fishery hauls were conducted either on or near stations from the regular ichthyoplankton station grid (see below) or on north-south transects through the Bornholm Basin. Fishery operations were conducted during day time, i.e. the feeding period of both species (Köster and Schnack 1994). Trawl hauls were targeting fish aggregations identified by a ship-mounted Simrad EK 60 scientific echosounder and performed with a general duration of 30-minutes at a speed of ca. 3 knots. Sprat and herring stomachs were taken by 1 and $2 \mathrm{~cm}$ fish length-classes, respectively and 132 immediately after weighting and measuring the fish and the stomachs were dissected 133 and preserved in borax-buffered $4 \%$ formaldehyde-seawater solution.

134 In the lab, the wet weight of stomach contents was estimated as difference between full 135 and emptied stomach. The stomach contents were transferred into sorting solution 136 (Steedman 1976) and were later analysed to major taxonomic groups using an 137 identification key by Kazanova (1953). The handling of stomachs followed the same 138 standardized procedure described in Köster (1994) and Köster and Schnack (1994). 
140 Hydroacoustic data were recorded continuously during survey operations with a hull141 mounted Simrad EK 60 scientific echosounder operated at $38 \mathrm{kHz}$ at a ship speed of $142 \sim 10$ knots, after a standardized calibration of hydroacoustic equipment prior to survey 143 operations (Foote et al. 1986). Clupeid school echoes were identified and integrated 144 using Echoview software (with an implemented school-detection algorithm (Echoview 145 Software Pty Ltd 2015). School detection parameters were set according to Nilsson et 146 al. (2003) and implemented on daytime data, taking diurnal vertical migration into 147 account.

Ichthyoplankton samples were collected on a regular station grid (on average 33 150 stations per cruise, with $\sim 9 \mathrm{nmi}$ distance, Fig. 1) covered with double-oblique hauls 151 using a Bongo net (335 to $500 \mu \mathrm{m}$ mesh size) from the surface to $\sim 3 \mathrm{~m}$ above the 152 bottom, following procedures described by Wieland (1988). For the estimation of cod 153 egg abundances, only stations within the $60 \mathrm{~m}$ depths contour were utilised (defined as 154 Bornholm Basin). This area was consistently covered over the entire time series and 155 contains the vast majority of the egg production by the stock (> 95\%; Wieland and Jarre, 156 1997). Data on the vertical distribution of cod eggs originate from a Hydrobios multi157 opening and -closing net consisting of 9 nets (335 $\mu \mathrm{m}$ mesh size), deployed at a towing 158 speed of 3 knots. Two (spring 2006) or three vertical profiles were sampled per cruise 159 (Fig. 1). Bongo and multinet samples were preserved in $4 \%$ borax-buffered 160 formaldehyde seawater solution. Fish eggs were identified from subsamples to species 161 level and development stage (Kazanova 1953) (min. 100 eggs per station) and risen to 162 the total sample volume. The volume of filtered water and water depth per station were 
163 used to calculate the total cod egg abundance $\left(n \mathrm{~m}^{-2}\right)$. To estimate vertical fish egg 164 distribution, the volume of filtered water per depth stratum was utilised to compute 165 densities $\left(n \mathrm{~m}^{-3}\right)$.

166 Diet composition and ichthyoplankton sampling, data processing and analyses in the 167 1990s and in 2000s followed similar procedures and are therefore directly comparable.

\section{Daily consumption of predators}

170 To estimate the amount of the daily food intake by individual herring and sprat an 171 exponential form of the general model of gastric evacuation was applied according to 172 the procedure used by Köster and Möllmann (2000) which incorporates the actual 173 ambient temperature as a variable and considers the type of food (Temming 1996, see 174 also Möllmann and Köster, 1999)

$$
S_{t}=S_{0} \times e^{-R^{\prime} \times t \times e^{A \times C}}
$$

175

with: S: stomach contents in terms of wet weight $(g), R^{\prime}$ : food type constant, A:

177 temperature coefficient, $\mathrm{C}$ : ambient temperature $\left({ }^{\circ} \mathrm{C}\right)$ and $\mathrm{t}$ : time interval. This function 178 was fitted to median stomach contents as well as to corresponding 25th and 75th 179 percentiles derived from 24-h fisheries and deck tank experiments performed in the 180 Bornholm Basin (STORE 2003, Temming 1996). The determined values for the food 181 type constant and the temperature coefficient were 0.084 and 0.129 for herring and 1820.108 and 0.073 for sprat, respectively. 
184 Following a procedure suggested by Pennington (1985) the average individual daily 185 ration $\left(\mathrm{F}_{\mathrm{T}}\right)$ of individual herring and sprat was estimated by: 186

$$
\mathrm{F}_{\mathrm{T}}=\mathrm{R}^{\prime} \times \mathrm{S} \times \mathrm{T} \times \mathrm{e}^{\mathrm{A} \times \mathrm{C}}+\mathrm{S}_{\mathrm{t}}-\mathrm{S}_{0}
$$

188 with T: duration of the daily feeding period of sprat and herring (hours of daylight; Köster 189 and Schnack 1994, Fetter and Davidjuka 1996) and $S_{t}$ and $S_{0}$ : the average stomach 190 content at the end and the beginning of the feeding period, respectively (Köster 1994).

191 Average ambient temperatures (C) in the area of $60-80 \mathrm{~m}$ water depth collected on the 192 station grid during the ichthyoplankton/hydrographic surveys (Fig. 1) with a vertically 193 deployed CTD-ADM probe were used or (in case of missing values) the data were 194 derived from the ICES Oceanographic Database. $S_{t}$ and $S_{0}$ were calculated as mean 195 relative deviations from the average stomach content during daytime, $2 \mathrm{~h}$ after sunrise 196 and 2 h before sunset, when food ingestion commenced and stopped (Köster 1994). 197 The daily ration of fish eggs was derived assuming the same ratio between daily food 198 intake and 
199 average stomach content for eggs in numbers as for daily food intake and total food in 200 weight. Finally, the daily ration of cod eggs ingested was calculated by partitioning the 201 daily ration of all fish eggs according to the determined species composition. Generally, 202 all unidentified fish eggs found in the stomachs could be raised to the proportions of 203 identified eggs with an exception of sprat diet composition in spring 2005 and 2008. 204 Therefore, for these dates, daily rations of unidentified fish eggs were provided.

\section{Predator distribution and abundance}

207 The effective predator abundance was considered to be represented by sprat and 208 herring abundances within the time and area of cod spawning. The cod spawning area 209 was defined as the area in the Bornholm Basin with water depths of $60 \mathrm{~m}$ and deeper 210 (Wieland 1988). The official stock assessments of sprat and herring cover larger areas 211 in the Baltic Sea and thus had to be downscaled to obtain the estimates of effective 212 predator abundances (see Fig. 2). The downscaling followed two steps. At first, we 213 derived abundance estimates of sprat and herring in ICES Subdivision (SD) 25 on 214 quarterly basis (mid May and mid July) from area-disaggregated multi-species SMS 215 model runs (Eero et al. 2012b). SD25 includes the defined spawning area of cod, 216 however also adjacent areas. Therefore, in a second step the estimates for SD25 had to 217 be further downscaled. This was done using both data and results of ICES coordinated 218 hydroacoaustic surveys as well as hydroacoustic measurements conducted during the 219 stomach sampling/ichthyoplankton/hydrographic surveys that when combined allowed 
220 estimating relative abundances in- and outside the defined spawning area within SD25 221 (see Table S ${ }^{1}$ ).

222

223 Horizontal distribution and abundance

224

225 To derive horizontal distribution and abundance indices of both sprat and herring in 226

240 Distribution and abundance indices of clupeids in summer were derived from the Baltic 241 International Acoustic Autumn Surveys (BIAS), assuming that distribution patterns in 242 September/October are also representative for clupeid distribution in summer after

\footnotetext{
${ }^{1}$ Table S1 with underlying data from figures is available in supplementary.
} 
243 finalization of spawning (Aro 1989). Contrary to the BASS spring surveys, NASC data 244 were not available for BIAS. Instead, evaluated, ICES rectangle based, species-specific 245 abundance indices were derived from annual survey reports (ICES Planning Group for 246 the Hydroacoustic Surveys in the Baltic, ICES 1990-1995; Baltic International Fish 247 Survey Working Group, ICES 1996-2009, Reports available from 248 http://www.ices.dk/community/groups/Pages/WGBIFS.aspx). Species specific 249 abundance indices (per $\mathrm{nmi}^{2}$ ) were derived for all rectangles within SD 25 and weighed 250 with the size of the area with water depths $\geq 60 \mathrm{~m}$ within each rectangle. As with the 251 spring data, distribution and abundance data then were combined to partition the total 252 abundance index for SD 25 into areas in- and outside the Bornholm Basin yielding 253 relative distributions of both herring and sprat for the corresponding areas. As the BIAS 254 survey coverage was either unavailable or considered insufficient in the years 1990, 2551993 and 1997, average abundance indices for these years were derived from 256 preceding and subsequent years.

258 Vertical distribution

260 As consumption estimates are highly influenced by predator-prey overlap, only 261 predators within the Bornholm Basin (see above) were considered that during their daily 262 feeding period (e.g. Köster and Schnack 1994) actually were dwelling in water layers 263 where cod egg predation can occur ( $\geq 50 \mathrm{~m}$, see Neumann et al. 2014). As the spatial 264 and temporal coverage of the ICES coordinated surveys was considered too low to 265 derive representative vertical distributions of clupeids within the Bornholm Basin, 
266 hydroacoustic data measured during the stomach sampling surveys (see above) were 267 used. The relative distribution of clupeid NASC values from those surveys recorded 268 during daytime (the daily feeding period of clupeids) was partitioned and aggregated 269 into layers above and below $50 \mathrm{~m}$ depth. To estimate the actual fraction of predators 270 overlapping with eggs, the ratio of clupeids below $50 \mathrm{~m}$ depth was applied to the relative 271 proportion of herring and sprat within the Bornholm Basin generated from horizontal 272 distribution data. As highly resolved vertical distribution data was only available for the 273 years 2004-2008, the average fraction of clupeids distributed in deeper layers in these 274 years was applied to calculate corresponding abundances for the preceding years.

276 Total Predator abundance

277

278 Obtained fractions of herring and sprat in- and outside of the cod spawning area within 279 SD 25 were utilized to downscale abundance of age 2+ sprat and herring in the entire 280 SD 25 (from stock assessment model) to the actual cod spawning area delineated by 281 the $60 \mathrm{~m}$ isobaths. In spring 1995 and 2004, considerable numbers (> 10\% of total 282 abundance) of age 1 sprat were encountered in the central Bornholm Basin during the 283 stomach sampling surveys. Accordingly, in these seasons/years, sprat age 1 284 abundance was also included in the calculation of total predator abundance to account 285 for that observation.

\section{Cod egg abundance and production}


289 Average stage-specific cod egg abundances from stomach samples were standardized 290 to spatial densities $\left(\mathrm{n} \mathrm{m}^{-2}\right)$ and raised to the area enclosed by the $60 \mathrm{~m}$ depth contour $291\left(11850 \mathrm{~km}^{2}\right)$. Dead cod eggs were included in abundances estimates, since dead and 292 live eggs cannot be distinguished in predator gastric contents.

294 The daily cod egg production was calculated by dividing the average stage-specific 295 abundances of egg stage IA by the development time of the egg stage. The latter is 296 dependent on ambient temperatures (Wieland et al. 2000a), which were derived from 297 hydrographic measurements taken during the vertically resolved ichthyoplankton 298 sampling (according to Wieland and Jarre, 1997). In cases where this was not available, 299 average temperature at 60-80m depths derived from the ICES oceanographic database 300 for May/June and July/August were applied. This water layer consistently contained $\geq$ $30195 \%$ of all cod eggs in vertically resolved ichthyoplankton sampling (Wieland and Jarre 302 1997). Egg mortalities from stage IA to IB were calculated for each survey according to 303 Wieland (1988) and results were then averaged over the time period 1990-2008 to 304 correct the daily egg production estimates for egg mortality within half stage duration 305 time of egg stage IA. Similar to the egg abundance, the corresponding proportion on 306 dead eggs per stage were added to the resulting egg production estimates.

\section{Results}

309 Daily food rations of herring and sprat

310 The daily food ration of individual herring was on average higher in spring than in 311 summer (Table 1), being similar in the 1990s and in the 2000s. In 2000s spring 
312 sampling dates, the daily ration of fish eggs varied from below 20 eggs $d^{-1}$ in 2004 and 3132005 to a maximum of $\sim 363$ fish eggs $\mathrm{d}^{-1}$ in 2008 . The main fraction of fish eggs were 314 cod (an average of 63\%). In contrast, in the 1990s, the daily rations of herring 315 contained on average $34 \%$ cod eggs only (Table 1 ). In summer 2004-2008, the daily 316 ration of fish eggs ranged between $\sim 5$ eggs $d^{-1}$ (2008) and $\sim 174$ eggs $d^{-1}$ (2007) per 317 herring, with an average of $>90 \%$ of these being cod eggs. Generally higher quantities

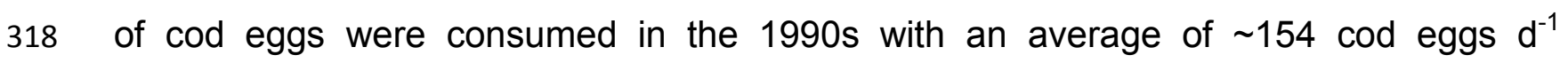

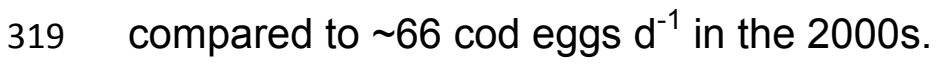

321 The daily food ration of individual sprat was similar in spring and summer. In spring of 322 the 2000s, overall low amounts of fish eggs were ingested by sprat $\left(\sim 11\right.$ eggs $\mathrm{d}^{-1}$ on 323 average), however a relatively high proportion of those were cod with a maximum $\sim 23$ 324 cod eggs $\mathrm{d}^{-1}$ (2007). In the 1990s generally higher numbers of fish eggs (78 eggs $\mathrm{d}^{-1}$ on 325 average) were consumed, however with a low proportion of cod eggs (max. 27 cod 326 eggs $\mathrm{d}^{-1}$ ). Maximum daily rations were encountered early and late in the 1990's and in 3272007 (Table 1). In summer, the consumption of cod eggs by individual sprat has always 328 been relatively low (max. 15 cod eggs $\mathrm{d}^{-1}$ ) with the exception of 1997 ( 58 cod eggs $\mathrm{d}^{-}$ $\left.329{ }^{1}\right)$.

331 Predator abundance

332 The predator abundance in the Bornholm Basin within the cod spawning area was 333 estimated to be well below 50\% of the total stock size in SD 25, except spring 2005 with 334 around $60 \%$. 
335 Herring abundance in summer was generally higher in the 1990 s $\left(\sim 300 * 10^{6}\right.$ on 336 average) compared to the 2000 s $\left(\sim 160 * 10^{6}\right)$, however with a relative high abundance 337 in $2007\left(\sim 360 * 10^{6}\right)$. The abundance of sprat in the Bornholm Basin was in most years 338 considerably higher than that of herring (on average $85 \%$ and $72 \%$ of the total clupeid 339 abundance in spring and summer, respectively) (Fig. 3; Table S1 ${ }^{1}$ ). Sprat abundance in 340 spring increased over tenfold from early to mid-1990s, levelling off during the late 1990s 341 and declining in the 2000 s to levels similar to the early 1990 s. Very low numbers of 342 sprat were encountered in spring 2008 (Fig. 3; Table SError! Bookmark not 343

347 higher compared to summer.

\section{Prey abundance}

350 Cod egg abundances have in general been higher in summer than in spring, with the 351 exception of 1991, 1997 and 2008 (Fig. 3; Table S1 ${ }^{1}$ ). A distinct peak in cod egg 352 abundance was observed in the mid-1990s, when between $\sim 550$ and nearly $1000 * 10^{9}$ 353 cod eggs were recorded in the spawning area, followed by low values in the late 1990s 354 (Fig. 3). In the 2000s, an increase in cod egg abundance was obvious both in spring 355 and summer. In spring, cod egg abundances increased from $\sim 100 * 10^{9}$ cod eggs in 356 2004 to over $300 \mathrm{cod}^{*} 10^{9}$ eggs in 2008 and in summer from $\sim 150$ to $\sim 400 * 10^{9} \mathrm{cod}$ 

357 eggs in 2006 with a slightly decrease to below 300 cod $^{*} 10^{9}$ eggs in 2008 (Fig. 3; 358 Table S ${ }^{1}$ ).

\section{Cod egg predation}

361 In general, with a few exceptions, sprat was the top predator of cod eggs in spring 362 (except 1993, 1994, 2006 and 2008), while herring dominated in summer (except 1997 363 and 2004) (Fig. 4, Table S1 ${ }^{1}$ ). Comparing the daily cod egg consumption rates in the 364 1990s and 2000s, similar values were estimated for herring in spring, while the 365 consumption in summer was higher in the 1990s.

366 Sprat on average consumed lower amounts of cod eggs in the 2000s compared to the 367 1990s, both in spring and summer, but with high variability especially in spring (Fig. 4, 368 Table $S 1^{1}$ ).

369 In terms of overall predation pressure, daily consumption of both predator species 370 combined exceeded the total egg abundance in spring 1992, 1998 and summer 1997 371 (Table S1 ${ }^{1}$ ) and egg production of stage IA in spring 1990-1993, 1997, 1998 and 2004 372 (Fig. 4; Table S1 ${ }^{1}$ ).

373 In summer, consumption rates were generally lower than production rates, except in 3741997 (Fig. 4; Table S1 ${ }^{1}$ ). The estimated level of consumption by the clupeid populations 375 in relation to the egg production suggests that predation has been of substantial 376 importance for cod egg mortality especially during spring in the 1990s. Independent of 377 the season, the daily consumption of cod eggs in relation to the daily production was 378 lower in the 2000s than in the 1990s, suggesting reduced predation pressure on cod 379 eggs in later years. 


\section{Discussion}

Inter-annual and seasonal variability in cod egg predation

383 The main predatory impact on cod eggs was exerted by sprat in spring and by herring in 384 summer, confirming earlier results by Köster and Möllmann (2000). Predation pressure 385 by clupeids was generally lower in the 2000s than in the 1990s, both in spring and 386 summer. This was related to a combination of lower individual daily rations and reduced 387 abundance of sprat and herring in spring and summer, respectively. al. 2005).

400 Predation on fish eggs is further affected by the availability of alternative prey with e.g. 401 better visibility (e.g., Sandström 1980, Segers et al. 2007). Herring prefer crustaceans 402 over fish eggs in the North Sea (Daan et al. 1985, Segers et al. 2007) and 
403 macrozooplankton, especially mysids, are the preferred prey in the Baltic Sea when 404 both prey types are available (Köster and Möllmann 2000, Casini et al. 2004). This 405 effect was apparent in our data in summer 2008, when herring preyed intensively on 406 mysids (Neumann et al. 2014), explaining the very low daily ration of cod eggs. 407 Similarly, sprat prefer cladocerans to fish eggs as prey (Köster and Möllmann 2000, 408 Bernreuther et al. 2013, Neumann et al. 2014). The relative warm intermediate water 409 layer observed regularly in summers of the 2000 s constituted an ideal habitat for sprat 410 (Stepputtis et al. 2011), which in combination with high abundance of cladocerans in 411 these water layers (Bernreuther et al. 2013) led to a low predation on cod eggs, which 412 were located in deeper water layers.

414 Apart from the vertical overlap and alternative prey availability, the horizontal overlap 415 between predator and prey further affects the predation pressure exerted by clupeids on 416 cod eggs. While sprat concentrate in the same areas as cod for spawning in spring and 417 early summer, they tend to leave the area after spawning (Aro 1989), which together 418 with changed vertical distribution explains the reduced predation pressure on cod eggs 419 by sprat in summer. In contrast, the abundance of herring in the cod spawning area was 420 low in spring, but increased in summer as spring spawning herring returned from the 421 spawning to their feeding grounds in the Bornholm Basin (Aro 1989). In addition to this 422 meso-scale change in distribution inside and outside of the Bornholm Basin, a large423 scale distribution shift from the southern central to the north-eastern areas in the Baltic 424 Sea has been observed for both clupeid species since the early 2000 s. This shift is 
425 more pronounced in sprat than in herring with sprat concentrating in the northern Baltic, 426 i.e. outside the cod spawning areas (Casini et al. 2011, Eero et al. 2012b).

Methodological uncertainties in the estimates

429 Earlier studies calculated cod egg consumption rates by clupeid populations in the 430 central Baltic to be several orders of magnitude higher than the daily egg production 431 rates (Köster and Schnack 2000). Our estimated daily consumption rates also exceeded 432 daily production in a number of occasions, especially in spring. Although this discrepancy is substantially reduced compared to earlier studies, it still indicates either 434 an overestimation of the egg consumption or an underestimation of the egg production. 435 Below we discuss the methodological challenges encountered in the present study.

437 Firstly, an exponential evacuation model was applied in our study, in agreement with 438 findings of Jobling (1986). However, Bernreuther et al. (2009) found a significant 439 deviation from an exponential function of gastric evacuation curve, resulting in an 440 underestimation of consumption rates at low stomach contents, and an overestimation 441 at high stomach contents, with identical consumption rates for both methods at a 442 stomach content of $3 \%$ body weight. In the present study, the stomach contents were 443 on average ca. $1 \%$ body weight or lower indicating that the choice of an exponential 444 evacuation model may have underestimated consumption rates, which therefore cannot 445 explain the estimated high consumption rates of cod eggs relative to production. 446 Further, a similar evacuation rate for fish eggs and other prey organisms was assumed. 447 The low proportion of fish eggs identifiable to species level indicates a rapid digestion 
448 beyond identification in sprat, but the remains of eggs can be identified after several 449 hours of digestion, thus being in the order of magnitude determined for 450 mesozooplankton prey (Köster 1994). Therefore, the applied procedure to assume that 451 fish egg shells are evacuated together with other food appears to be more reasonable 452 than to model the digestion rate of fish eggs separately (Köster and Schnack 1994).

454 Secondly, the estimation of predator abundances within the Bornholm Basin is a source 455 of uncertainty involving two geographical down-scaling steps. Earlier analyses found 456 that sprat abundances estimated directly from hydroacoustic surveys were consistently 457 lower compared to the values from stock assessments after downscaling using relative 458 distribution patterns from hydroacoustic surveys (Köster and Möllmann 2000). This 459 could imply a consistent overestimation of the predator population size (Köster et al. 460 2005). To explore this effect, alternative predation rates were calculated using predator 461 abundances from hydrographic surveys directly (results not shown), which had a limited 462 effect on inter-annual variability in predation pressure and could not reduce the 463 relatively high consumption rates compared to egg production estimated for spring of 464 the early and late 1990's and 2004. For herring, higher abundances were estimated 465 when using hydroacoustic surveys directly, which would indicate that predation pressure 466 is rather under- than overestimated. Using an average value of the spring fractions of 467 both herring and sprat distributed within the BB in the years 1999-2008 for earlier years 468 with no such distribution data may introduce an error. However, as the overall variance 469 in spatial distribution of both species was low in the years with available data, this error 470 is considered to be of limited concern. Applying acoustic surveys conducted in autumn 
471 to represent relative distribution of clupeids in summer may as well bias the results.

472 Earlier analyses for the 1980s showed that a lower proportion of both herring and sprat

473 was located in the Bornholm Basin in summer than in autumn. However, the 474 encountered deviation was quite limited for herring that is the main predator on cod 475 eggs in summer (Köster 1994).

476

477 Finally, in addition to possibly overestimating consumption, the cod egg production may 478 be underestimated. The coverage of the spawning area by the ichthyoplankton station 479 grid is considered sufficient as cod eggs need salinities > 11 PSU to be neutrally 480 buoyant (e.g., Wieland and Jarre 1997). Such conditions only prevail in the central 481 Bornholm Basin that is well covered by the surveys. However, Kraus et al. (2002) 482 obtained by a factor of 2 higher potential egg production estimates based on the 483 abundances of female spawning cod and their fecundity than the egg production values 484 derived from ichthyoplankton surveys. This can be explained by the loss of eggs as a 485 result of atresia, fertilization failure, and mortality during early embryogenesis (Kraus et 486 al. 2002). In our calculations we have taken, in contrast to earlier studies (e.g. Köster 487 and Möllmann 2000, Voss et al. 2011), into account the mortality within egg stage IA, 488 but fertilization success is not considered and it is unclear how fast the non-fertilized 489 eggs are sinking to the bottom.

491 In conclusion, the cases in which egg consumption rates still exceed production 492 estimates are likely related to an underestimation of the daily egg production, while in 
493 contrast to earlier studies (Köster and Möllmann 2000, Köster et al. 2005) the 494 determination of predation population sizes appears to be substantially improved. 495 496 Clupeid predation as a source of mortality on early life stages

497 Our results confirm that predation on cod eggs by sprat and herring is at times a 498 substantial source of early life stage mortality. Especially during spring, i.e. early in the 499 spawning season of cod, sprat may exert high predation pressure on cod eggs. A 500 gradual shift in peak spawning time in the last decades from spring to summer (Wieland 501 et al. 2000b) has thus decreased cod egg mortality due to predation by clupeids. The 502 lower predation pressure in the 2000 s compared to the 1990 s was related to generally 503 lower predator population sizes of sprat in spring and herring in summer as well as 504 reduced individual daily egg rations of especially herring in summer. The latter is in line 505 with a limited spatial overlap between predator and prey in the later period (Neumann et 506 al. 2014).

508 Other potential predators, such as chaetognaths, sticklebacks (Gasterosteidae), moon 509 jellyfish (Aurelia aurita) and garfish (Belone belone) show only limited horizontal, vertical 510 or temporal overlap with cod eggs. Even if spatial overlap occurs, these predators are 511 either not able to detect or capture the motionless and relatively large eggs (Köster and 512 Schnack 1994, STORE 2003). In later years the ctenophore Mnemiopsis leidyi has 513 been suspected to be a substantial predator on cod early life stages. In 2007, M. leidyi 514 was highly abundant in the Bornholm Basin with variable inter-seasonal distribution and 515 overlap with cod eggs (Haslob et al. 2007). However, the studies conducted so far did 
516 not find a strong impact on cod egg predation (Schaber et al. 2011, Jaspers et al. 2011).

517 Only scyphomedusae of Cyanea capillata have been identified as predators on cod 518 eggs of some importance (Margonski and Horbowa 1996, Barz and Hirche 2005), but 519 their abundances and thus likely also predation rates are comparatively low (Barz et al. 520 2006).

521

522 Clupeid predation on later life stages of cod, i.e. larvae and early juveniles appears to 523 be low as well, caused by a combination of limited vertical overlap and size preferences 524 (Köster and Schnack 1994, Köster and Möllmann 1997). Thus, egg predation by 525 clupeids seems the primary source of early life stage predation mortality. 526

527 Predation on fish early life stages has been identified as an issue also in other areas. In 528 the northern Gulf of St. Lawrence a 15 -fold decline of cod biomass has been recorded 529 from the mid-1980s to the mid-1990s (Morissette et al. 2003). Similar to the cod stock in 530 the central Baltic, predation on early life stages by pelagic fish is assumed to have a 531 strong negative effect on cod recruitment success (Savenkoff et al. 2004). Field studies 532 to quantify the predation on cod eggs by planktivorous fish have also been conducted in 533 the North Sea and the Lofoten area. In contrast to the Baltic, the impact of egg 534 predation by herring is quite limited in the North Sea (Daan et al. 1985) and low in the 535 Northeast Arctic as well (Melle 1985). This can be explained by a limited vertical overlap 536 between cod eggs and clupeids in these systems during their main daily feeding period 537 compared to the central Baltic Sea and other estuarine sea areas. 
539 In order to assess the relative importance of predation by clupeids for the reproductive 540 success of cod in the central Baltic, other sources of early life stage mortality need to be 541 taken into account as well. Predation on cod eggs will have a limited effect on 542 recruitment if the eggs and later pre-recruit life stages are anyway subject to high 543 mortality due to other reasons such as poor hydrographic ambient conditions for 544 successful egg development (Köster et al. 2005) or insufficient food supply for cod 545 larvae (Hinrichsen et al. 2001).

546

547 Especially the lack of oxygen in and below the halocline is a major source of egg 548 mortality in stagnation periods (Plikshs et al. 1993), also affecting larval activity (Rohlf 549 1999). However, even in a stagnation situation, for example in spring 2002, the daily 550 egg mortality rates due to predation by clupeids were estimated to be higher than 551 mortality rates due to low oxygen concentration (Voss et al. 2011).

An important factor for recruitment success of cod is prey availability for first feeding 554 larvae (Hinrichsen et al. 2002, Möllmann et al. 2005). Huwer et al. (2011) reported a 555 significantly better larval growth in 2007 compared to the mid-1990s, thus larval survival 556 may have improved in the latter half of the 2000s, potentially enhancing recruitment.

558 Estimating annual variations in recruitment of the eastern Baltic cod in later years is 559 presently hampered by lack of quantitative stock assessment and age information for 560 cod (Eero et al. 2015). However, survey information shows increased abundances of 561 small cod in the mid-late 2000s, which suggest the occurrence of some relatively 
562 stronger year-classes, which have contributed to the observed increase in stock size in 563 the late 2000s (ICES 2016).

564

565 Our analyses suggest that predation pressure on early life stages of cod has generally 566 been lower in the 2000s compared to the 1990s, which, in combination with other 567 factors, likely contributed to a relatively higher recruitment, at least in some years. As a 568 next step, dedicated analyses integrating the available information on all major factors 569 influencing cod recruitment would be worthwhile to conduct, to improve our 570 understanding of the relative importance of different processes acting on cod 571 recruitment. Our study contributes to this process with improved and updated 572 quantitative estimates of egg predation. Improved process understanding of recruitment 573 dynamics in the Baltic Sea may also be helpful for interpreting changes in recruitment in 574 comparable systems elsewhere, where similar comprehensive datasets that allow 575 quantifying complex processes like egg predation may not be available.

\section{Acknowledgements}

578 The research leading to these results has received funding from BONUS (BIO-C3 579 project), the joint Baltic Sea research and development programme (Art 185), funded 580 jointly by the European Union's Seventh Framework Programme for Research, 581 Technological Development and Demonstration and Innovation Fund Denmark. We 582 thank the crews of the various involved research vessels, especially of RV 583 "Alkor"conducting the majority of the surveys as well as everybody involved in 584 sampling, technical support, and analyzing the plankton and stomach samples. We also 
585 like to thank the two anonymous reviewers for giving useful comments and suggestions 586 to an earlier version of this paper.

\section{Literature cited}

Aro, E. 1989. A review of fish migration patterns in the Baltic. Rapport Procès-verbaux des Réunion du Conseil International pour l'Exploration de la Mer, 190: 72-96.

Bagge, O., Thurow, F., Steffensen, E., and Bay, J. 1994. The Baltic Cod. Dana 10: 128.

Bailey, K.M., and Houde, E.D. 1989. Predation on Eggs and Larvae of Marine Fishes and the Recruitment Problem. Adv. Mar. Biol. 25: 1-83.

Barz, K., and Hirche, H.J. 2005. Seasonal development of scyphozoan medusae and the predatory impact of Aurelia aurita on the zooplankton community in the Bornholm Basin (central Baltic Sea). J. Mar. Biol. 147: 465-476. doi:10.1007/s00227-005-1572-2.

Barz, K., Hinrichsen H.H., and Hirche, H.J. 2006. Scyphozoa in the Bornholm Basin (central Baltic Sea) -The role of advection. J. Mar. Sys. 60: 167-176. doi:10.1016/j.jmarsys.2006.01.002.

Bernreuther, M., Schmidt, J., Stepputtis, D., and Temming, A. 2013. Vertically resolved prey selectivity and competition of Baltic herring Clupea harengus and sprat Sprattus sprattus. Mar. Ecol. Prog. Ser. 489: 177-195. doi:10.3354/meps10405

Bernreuther, M., Temming, A., and Herrmann, J.P. 2009. Effect of temperature on the gastric evacuation in sprat Sprattus sprattus. J. Fish. Biol. 75: 1525-1541. doi:10.1111/j.1095-8649.2009.02353.x 
608 Casini, M., Cardinale, M., and Arrhenius, F. 2004. Feeding preferences of herring 609 610 611 612 613 614 615 616 617 618 619 620 621 622 623 624 625 626 627 628 629 630

Daan, N., Rijnsdorp, A.D., and Overbeeke, G.R. 1985. Predation by North Sea herring Clupea harengus on eggs of plaice Pleuronectes platessa and cod Gadus morhua. Trans. Am. Fish. Soc. 114: 499-506. doi:10.1577/15488659(1985)114<499:PBNSHC>2.0.CO;2.

Echoview Software Pty Ltd 2015. Echoview software, version 6. Echoview Software Pty Ltd, Hobart, Australia.

Eero, M., Köster, F.W., and Vinther, M. 2012a. Why is the Eastern Baltic cod recovering? Mar. Policy 36: 235-240. doi:10.1016/j.marpol.2011.05.010.

Eero, M., Vinther, M., Haslob, H., Huwer, B., Casini, M., Storr-Paulsen, M., and Köster, F.W. 2012b. Spatial management of marine resources can enhance the recovery of predators and avoid local depletion of forage fish. Conserv. Lett. 5(6): 486-492. doi:10.1111/j.1755-263X.2012.00266.x.

Eero, M., Hjelm, J., Behrens, J., Buchmann, K., Cardinale, M., Casini, M., Gasyukov, P., Holmgren, N., Horbowy, J., Hüssy, K., Kirkegaard, E., Kornilovs, G., Krumme, U., Köster, F.W., Oeberst, R., Plikshs, M., Radtke, K., Raid, T., Schmidt, J., 
631

632

633

634

635

636

637

638

639

640

641

642

643

644

645

646

647

648

649

650

651

652

Tomczak, M.T., Vinther, M., Zimmermann, C., and Storr-Paulsen, M. 2015. Food for Thought: Eastern Baltic cod in distress: biological changes and challenges for stock assessment. ICES J. Mar. Sci. 72: 2180-2186. doi:10.1093/icesjms/fsv109.

Fetter, M., and Davidjuka, A. 1996. Herring daily feeding activity in the eastern Baltic Sea. ICES CM J:26.

Foote, K.G., Aglen, A., and Nakken, O. 1986. Measurement of fish target strength with a split-beam echosounder. J. Acoust. Soc. of Am. 80: 612-621. doi:10.1006/jmsc.2002.123.

Garrison, L.P., Michaels, W., Link, J.S., and Fogarty, M.J. 2000. Predation risk on larval gadids by pelagic fish in the Georges Bank ecosystem I. Spatial overlap associated with hydrographic features. Can. J. Fish. Aquat. Sci., 57: 2455-2469.

Hallfredsson, E.H., and Pedersen, T. 2009. Effects of predation from juvenile herring (Clupea harengus) on mortality rates of capelin (Mallotus villosus) larvae. Can. J. Fish. Aquat. Sci. 66: 1693-1706. doi:10.1139/F09-105.

Haslob, H., Clemmesen, C., Schaber, M., Hinrichsen, H. H., Schmidt, J., Voss, R., Kraus. G., and Köster, F. W. 2007. Invading Mnemiopsis leidyi as a potential threat to Baltic fish. Mar. Ecol. Prog. Ser., 349, 303-306.

Heath, M. 1992. Field investigations of the early life stages of marine fish. Adv. Mar. Biol. 28: 173 pp.

Hinrichsen, H.-H., St. John, M., Aro, E., Grønkjær, P., and Voss, R. 2001. Testing the larval drift hypothesis in the Baltic Sea: retention versus dispersion caused by 
653

654

655

656

657

658

659

660

661

662

663

664

665

666

667

668

669

670

671

672

673

674

675

wind-driven circulation. ICES J. Mar. Sci. 58: 973-984. doi:10.1006/jmsc.2001.109.

Hinrichsen, H.-H., Möllmann, C., Voss, R., and Köster, F.W. 2002. Biophysical modeling of larval Baltic cod (Gadus morhua) growth and survival. Can. J. Fish. Aquat. Sci. 59: 1858-873. doi: 0.1139/F02-149.

Houde, E.D. 2008. Emerging from Hjort's Shadow. J. Northwest Atl. Fish. Sci., 41: 5370. doi:10.2960/J.v41.m634.

Huwer, B., Clemmesen, C., Grønkjær, P., and Köster, F.W. 2011. Vertical distribution and growth performance of Baltic cod larvae - Field evidence for starvationinduced recruitment regulation during the larval stage? Prog. Oceanogr. 91: 382396. doi.org.globalproxy.cvt.dk/10.1016/j.pocean.2011.04.001.

ICES, 2015. Report of the Baltic Fisheries Assessment Working Group (WGBFAS), $12-$ 19 April 2016 ICES HQ, Copenhagen, Denmark, ICES CM 2016/ACOM:11.

Jaspers, C., Titelman, J., Hansson, L.J., Haraldsson, M., and Ditlefsen, C.R. 2011. The invasive ctenophore Mnemiopsis leidyi poses no direct threat to Baltic cod eggs and larvae Limnol. Oceanogr. 56(2): 431-439. doi:10.4319/lo.2011.56.2.0431.

Jobling, M. 1986. Mythical models of gastric emptying and implications for food consumption studies. Environ. Biol. Fish. 16: 35-50. doi:10.1007/BF00005158.

Kazanova. I.I. 1953. Key for identification of the eggs and larvae of fishes of the Baltic Sea and its inlets. Trudy VNIRO 26: 221-265 (in Russian).

Kornilovs, G., Sidrevics, L., and Dippner, J.W. 2001. Fish and zooplankton interaction in the central Baltic Sea. ICES J. Mar. Sci. 58: 579-588. doi:10.1006/jmsc.2001.106. 
676 Köster, F.W. 1994. Der Einfluss von Bruträubern auf die Sterblichkeit früher 677 Jugendstadien des Dorsches (Gadus morhua) und der Sprotte (Sprattus 678 679 680 681 682 683 684 685 686 687 688 689 690 691 692 693 694 695 696 697 sprattus) in der zentralen Ostsee. Ph.D. thesis, Berichte Institut für Meereskunde Kiel 261: 286 pp.

Köster, F.W., and Möllmann, C. 2000. Trophodynamic control by clupeid predators on recruitment success in Baltic cod? ICES J. Mar. Sci. 57: 310-323. doi:10.1006/jmsc.1999. 0528.

Köster, F.W., and Schnack, D. 1994. The role of predation on early life stages of cod in the Baltic. Dana 10: 179-201.

Köster, F.W., Möllmann, C., Neuenfeld, S., Vinther, M., St John, M.A., Tomkiewicz, J., Voss, R., Hinrichsen, H.H., Kraus, G., and Schnack, D. 2003. Fish stock development in the Central Baltic Sea (1976-2000) in relation to variability in the physical environment. ICES Mar. Sci. Symp. 219: 294-306.

Köster, F.W., Möllmann, C., Hinrichsen, H.-H., Wieland, K., Tomkiewicz, J., Kraus, G., Voss, R., Markarchouk, A., MacKenzie, B.R., St.John, M.A., Schnack, D., Rohlf, N., Linkowski, T., and Beyer, J.E. 2005. Baltic cod recruitment - the impact of climate variability on key processes. ICES J. Mar. Sci. 62(7):1408-1425. doi:10.1016/j.icesjms.2005.05.004

Köster, F.W., Vinther, M., Mac Kenzie, B., Eero, M., and Plikshs, M. 2009. Environmental Effects on Recruitment and Implications for Biological Reference Points of Eastern Baltic Cod (Gadus morhua). J. Northw. Atl. Fish. Sci. 41: 205220. doi:10.2960/J.v41.m636. 
698 Kraus, G., Tomkiewicz, J., and Köster, F.W. 2002. Egg production of Baltic cod (Gadus 699 morhua) in relation to variable sex ratio maturity and fecundity. Can. J. Fish.

Melle, W. 1985. Predasjon på torskens egg og larvar i Lofoten. Institutt for Fiskeribiologi, Universitetet i Bergen, 142 s, Norway.

Möllmann, C., Köster, F.W. 1999. Food consumption by clupeids in the Central Baltic: evidence for top-down control? ICES J. Mar. Sci. 56: 100-113. doi:10.1006/jmsc.1999.0630

Möllmann, C., Kornilovs, G., Fetter, M., and Köster, F.W. 2005. Climate zooplankton and pelagic fish growth in the Central Baltic Sea. ICES J. Mar. Sci. 62: 12701280.

Morissette, L., Despatie, S.P., Savenkoff, C., Hammill, M.O., Bourdages, H., and Chabot, D. 2003. Data gathering and input parameters to construct ecosystem models for the northern Gulf of St. Lawrence (mid-1980s). Can. Tech. Rep. Fish. Aquat. Sci. 2497: 94p. 
719 Neumann, V., Köster, F.W., Schaber, M., and Eero, M. 2014. Recovery in eastern Baltic 720 cod: is increased recruitment caused by decreased predation on early life 721

Plikshs, M., Kalejs, M., and Grauman, G. 1993. The influence of environmental conditions and spawning stock size on the year-class strength of the eastern Baltic cod. ICES CM J: 22.

Prodanov, K., Mikhailov, K., Daskalov, G. M. , Maxim, C., Chashchin, A., Arkhipov, A., Shlyakhov, V., and Ozdamar. E. 1997. Environmental management of fish resources in the Black Sea and their rational exploitation. United Nations Food and Agriculture Organization, Rome.

Rohlf, N. 1999. Verhaltensänderungen der Larven des Ostseedorsches (Gadus morhua callarias L) während der Dottersackphase. Ph.D. thesis, Berichte Institut für Meereskunde, Kiel 312: 52 pp. 
741 Rudstam, L.G., Aneer, G., and Hildén, M. 1994. Top-down control in the pelagic Baltic 742 ecosystem. Dana 10: 105-129.

Savenkoff, C., Bourdages, H., Castonguay, M., Morissette, L., Chabot, D., and Hammill, M.O. 2004. Input data and parameter estimates for ecosystem models of the northern Gulf of St. Lawrence (mid-1990s). Can. Tech. Rep. Fish. Aquat. Sci: 2531.

Schaber, M., Haslob, H., Huwer, B., Harjes, A., Hinrichsen, H.-H., Köster, F.W., StorrPaulsen, M., Schmidt, J.O., and Voss, R. 2011. The invasive ctenophore Mnemiopsis leidyi in the central Baltic Sea: seasonal phenology and hydrographic influence on spatio-temporal distribution patterns. J. Plankton. Res. 33: 1053-1065. doi:10.1093/plankt/fbq167.

Segers, F.H.I.D., Dickey-Collas, M., and Rijnsdorp, A.D. 2007. Prey selection by North Sea herring (Clupea harengus) with special reference to fish eggs. ICES J. Mar. Sci. 64: 60-68. doi:10.1093/icesjms/fsl002.

Simmonds, E.J., and MacLennan, D.N. 2005. Fisheries acoustics: theory and practice 2nd Edition. Blackwell Scientific Publications, Oxford, UK.

Sparholt, H. 1994. Fish species interactions in the Baltic Sea. Dana 10: 131-162.

Steedman, H.F. 1976. Osmotic pressure in fixation and preservation. In Monographs on Oceanographic Methodology, 4. Zooplankton Fixation and Preservation. UNESCO Press, Paris. 186 pp.

Stepputtis, D., Hinrichsen, H.-H., Böttcher, U., Götze, E., and Morholz, V. 2011. An example of meso-scale hydrographic features in the central Baltic Sea and their influence on the distribution and vertical migration of sprat Sprattus sprattus 
764

765

766

767

768

769

770

771

772

773

774

775

776

777

778

779

780

781

782

783

784

785

786

787

balticus (Schn). Fish Oceanogr 20: $\quad 82-88 . \quad$ doi:10.1111/j.13652419.2010.00567.x.

STORE, 2003. Environmental and fisheries influences on fish stock recruitment in the Baltic. Final Report to the EU Commission FAIR-98-3959. http://orbit.dtu.dk/files/125451756/STORE report.pdf

Swain, D.P., and Sinclair, A.F. 2000. Pelagic Fishes and the Cod Recruitment Dilemma. Can. J. Fish. Aquat. Sci. 57: 1321-1325. doi:10.1139/f00-104.

Temming, A. 1996. Die quantitative Bestimmung der Konsumtion von Fischen; Experimentelle methodische und theoretische Aspekte. Habilitation thesis, University of Hamburg: $235 \mathrm{pp}$.

Voss, R., Hinrichsen, H.-H., Stepputtis, D., Bernreuther, M., Huwer, B., Neumann, V., and Schmidt, J.O. 2011. Egg mortality: predation and hydrography in the central Baltic. ICES J. Mar. Sci. 68: 1379-1390. doi:10.1093/icesjms/fsr061.

Wieland, K. 1988. Distribution and mortality of cod eggs in the Bornholm Basin Baltic Sea in May and June 1986. Kieler Meeresforschungen Sonderheft 6: 331-340.

Wieland, K., and Jarre, A. 1997. Prediction of vertical distribution and ambient development temperature of Baltic cod Gadus morhua L eggs. Fish. Oceanogr. 6: 172-187. doi10.1046/j.1365-2419.1997.00038.x

Wieland, K., Hinrichsen, H.-H., and Grønkjær, P. 2000a. Stage-specific mortality of Baltic cod (Gadus morhua L) eggs. J. Appl. Ichthyol. 16(6): 266-272. doi:10.1046/j.1439-0426.2000.00241.x.

Wieland, K., Jarre-Teichmann, A., and Horbowa, K. 2000b. Changes in the timing of spawning of Baltic cod: possible causes and implications for recruitment. ICES J. Mar. Sci. 57: 452-464. doi:10.1006/jmsc.1999.0522. 
1 Table 1. Average daily ration of individual herring and sprat; ambient temperature [C; $\left.{ }^{\circ} \mathrm{C}\right]$;

2 feeding period [T; h], daily rations [FT; gram]; number of fish eggs per stomach (F/st) and

3 daily rations of fish (Feggs) and cod eggs (Fcod; all stages included) in numbers for spring

4 (May/ June) and summer (July/ August) per year and overall mean for the 1990s and

5 2004-2008. No data available between 2000-2003. * only unidentified eggs.

\begin{tabular}{|c|c|c|c|c|c|c|c|c|c|c|c|c|}
\hline \multirow{2}{*}{ season } & \multirow[b]{2}{*}{ year } & \multirow[b]{2}{*}{ month } & \multirow[b]{2}{*}{$\mathrm{C}$} & \multirow[b]{2}{*}{$\bar{T}$} & \multicolumn{4}{|c|}{ herring } & \multicolumn{4}{|c|}{ sprat } \\
\hline & & & & & FT & F/st & Feggs & Fcod & FT & F/st & Feggs & Fcod \\
\hline \multirow[t]{10}{*}{ spring } & 1990 & 6 & 6.4 & 17.1 & 2.0 & 11.9 & 46.1 & 20.6 & 0.4 & 54.8 & 210.6 & 15.3 \\
\hline & 1991 & 5 & 4.9 & 16.9 & 1.3 & 31.5 & 103.6 & 29.7 & 0.4 & 31.4 & 110.2 & 26.5 \\
\hline & 1992 & 5 & 5.7 & 16.4 & 1.2 & 3.1 & 10.9 & 0.0 & 0.3 & 46.9 & 167.9 & 5.9 \\
\hline & 1993 & 5 & 4.5 & 16.7 & 1.1 & 14.4 & 45.0 & 26.2 & 0.4 & 2.1 & 7.2 & 4.2 \\
\hline & 1994 & 6 & 3.8 & 17.1 & 1.3 & 16.5 & 49.1 & 44.0 & 0.4 & 11.2 & 37.5 & 4.2 \\
\hline & 1995 & 5 & 5.6 & 16.3 & 1.6 & 5.8 & 20.0 & 7.4 & 0.2 & 8.0 & 28.3 & 1.0 \\
\hline & 1996 & 5 & 3.5 & 16.4 & 1.0 & 5.0 & 13.8 & 4.8 & 0.3 & 3.3 & 10.5 & 2.0 \\
\hline & 1997 & $5 / 6$ & 5.3 & 16.9 & 1.1 & 44.4 & 153.1 & 26.2 & 0.3 & 27.3 & 98.0 & 20.2 \\
\hline & 1998 & 5 & 7.5 & 16.4 & 1.0 & 2.6 & 10.8 & 1.1 & 0.3 & 17.6 & 69.6 & 22.2 \\
\hline & 1999 & 5 & 6.6 & 16.4 & 2.6 & 2.9 & 11.0 & 1.7 & 0.5 & 9.9 & 37.4 & 0.6 \\
\hline \multicolumn{2}{|c|}{ average } & & & & & 27.4 & 100.9 & 81.9 & 0.3 & 2.7 & 10.8 & 7.6 \\
\hline & 2004 & 6 & 4.8 & 16.6 & 1.0 & 5.1 & 17.1 & 10.5 & 0.1 & 1.2 & 5.8 & 5.7 \\
\hline & 2005 & 5 & 5.7 & 16.5 & 1.5 & 2.1 & 7.3 & 2.8 & 0.3 & 1.0 & $3.9^{*}$ & $0.0^{*}$ \\
\hline & 2006 & 6 & 5.6 & 16.8 & 1.6 & 12.3 & 46.7 & 33.1 & 0.3 & 2.8 & 13.4 & 9.5 \\
\hline & 2007 & 5 & 5.6 & 16.5 & 2.0 & 14.2 & 70.6 & 39.7 & 0.4 & 5.8 & 23.6 & 22.7 \\
\hline & 2008 & 6 & 4.9 & 16.7 & 1.8 & 103.0 & 362.6 & 323.5 & 0.3 & 2.5 & $7.6^{*}$ & $0.0^{*}$ \\
\hline
\end{tabular}


average summer 1994 1995 199 199 average

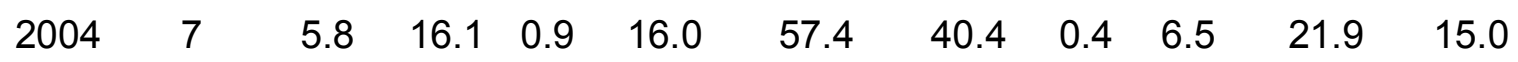
$\begin{array}{llllllllllll}2005 & 7 & 5.7 & 15.9 & 1.3 & 14.6 & 88.1 & 80.9 & 0.4 & 2.0 & 7.5 & 2.1\end{array}$ $\begin{array}{llllllllllll}2006 & 7 & 5.6 & 15.6 & 0.8 & 7.6 & 31.1 & 30.0 & 0.5 & 0.0 & 0.0 & 0.0\end{array}$ $\begin{array}{llllllllllll}2007 & 8 & 6.4 & 15.3 & 0.9 & 46.9 & 173.9 & 172.0 & 0.4 & 0.2 & 0.7 & 0.7\end{array}$ $\begin{array}{llllllllllll}2008 & 8 & 4.9 & 13.9 & 0.8 & 1.2 & 4.8 & 4.8 & 0.4 & 0.0 & 0.0 & 0.0\end{array}$ average

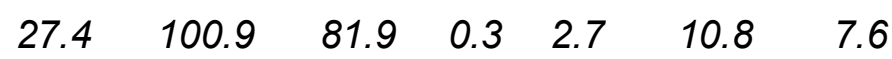
$\begin{array}{llllllllll}5.6 & 15.9 & 1.6 & 13.5 & 26.9 & 22.5 & 0.5 & 13.4 & 22.7 & 7.9\end{array}$

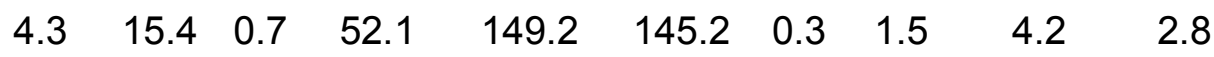
$\begin{array}{llllllllll}5.5 & 16.4 & 1.0 & 42.8 & 146.3 & 141.0 & 0.4 & 0.0 & 0.1 & 0.0\end{array}$ $\begin{array}{llllllllll}4.2 & 16.2 & 0.7 & 85.0 & 251.6 & 240.9 & 0.2 & 5.3 & 15.7 & 11.4\end{array}$ $\begin{array}{llllllllll}5.6 & 16.4 & 1.1 & 65.6 & 226.2 & 220.5 & 0.5 & 17.6 & 57.7 & 57.9\end{array}$ $\begin{array}{lllllll}51.8 & 160.0 & 154.0 & 0.4 & 7.5 & 20.1 & 16.0\end{array}$ $\begin{array}{lllllll}17.3 & 71.1 & 65.6 & 0.4 & 1.7 & 6.0 & 3.6\end{array}$ 


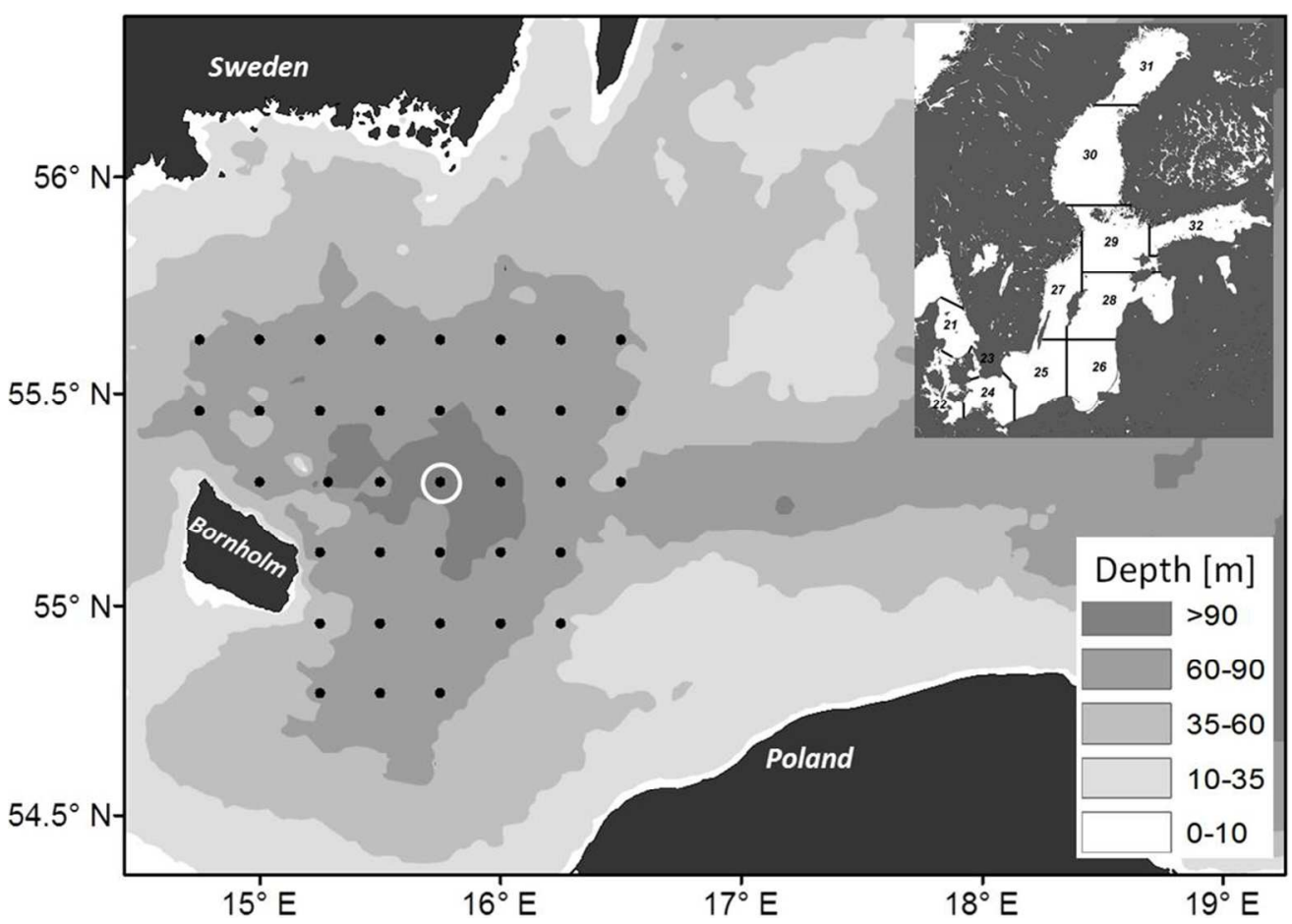

Fig. 1. Investigated area: Bornholm Basin (ICES subdivision 25) in the Baltic Sea (inlet) with the regular Bongo Station grid (black dots) and a Multinet station (circle), sampled between 2004-2008. Fishing was conducted on selected positions on or near stations from the regular grid or in central deep parts of the Bornholm Basin. 
Horizontal Distribution in SD 25 to derive proportion of fish inside BB Spring: Summer:

Hydroacoustic data from ICES BASS Abundance indices from ICES BIAS

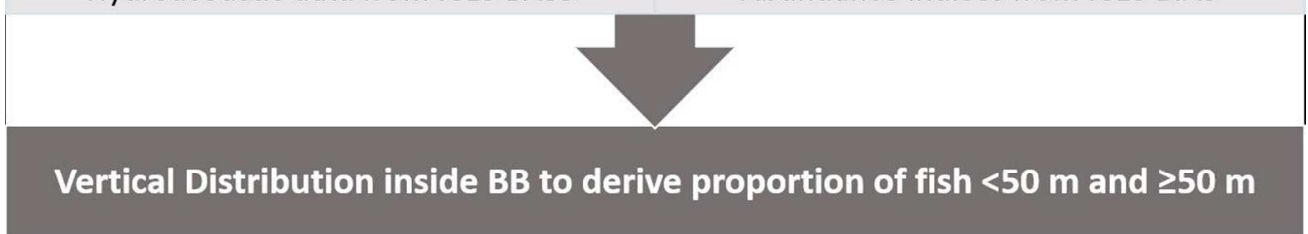

Hydroacoustic data from stomach sampling surveys

Total predator abundance inside $\mathrm{BB} \geq 50 \mathrm{~m}$

Downscaling of total abundance from area dis-aggregated SMS model runs with derived proportions

Fig. 2. Data sources and workflow applied to derive estimates of abundance of herring and sprat within layers of cod egg occurrence within the cod spawning area of the Bornholm Basin in ICES Subdivision (SD) 25. BASS - Baltic Acoustic Spring Survey; BIAS - Baltic International Acoustic Autumn Survey; BB - Bornholm Basin. 


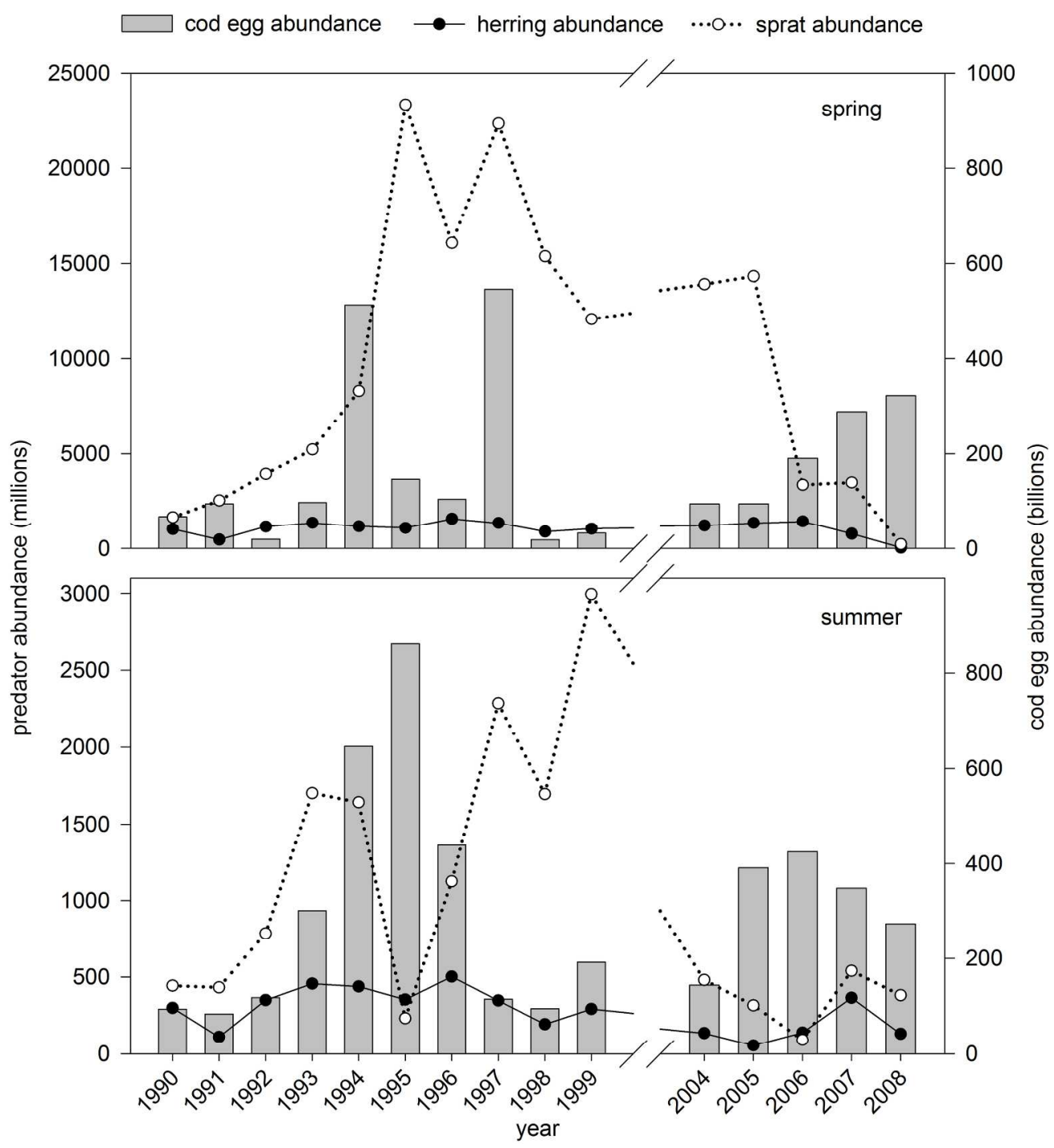

Fig. 3. Abundances of cod eggs (prey) and sprat and herring (predators) in spring (May/ June) and summer (July/ August) in the Bornholm Basin. No data available between 2000-2003.

$214 \times 232 \mathrm{~mm}(300 \times 300 \mathrm{DPI})$ 


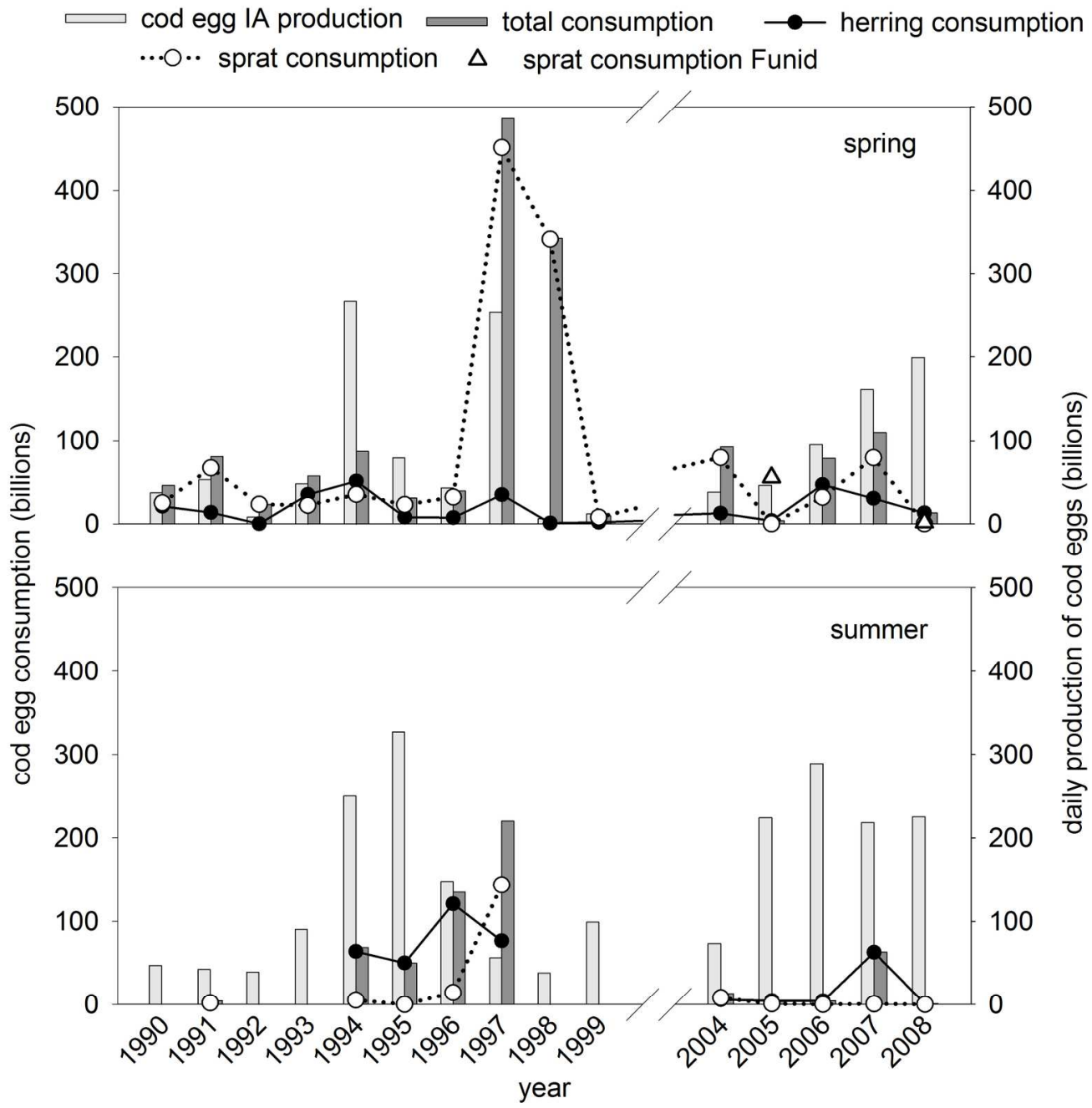

Fig. 4. Cod egg daily production and daily consumption rates, shown separately for sprat and herring populations and combined (clupeids) in the Bornholm. No data available between 2000-2003. Sprat consumption values in spring 2005 and 2008 are based on unidentified fish eggs. No consumption data available: summer 1990, 1992, 1993, 1998 and 1999.

$173 \times 176 \mathrm{~mm}(300 \times 300 \mathrm{DPI})$ 